Chapter 4

\title{
Canadian into Catalan: The Translation of Anglo-Canadian Authors in Catalonia
}

\author{
Isabel Alonso-Breto and Marta Ortega-Sáez
}

\section{Catalonia's Singularity and Parallelisms with Quebec ${ }^{87}$}

Although it may seem disconcerting to begin this chapter about the translation of Anglo-Canadian writers into Catalan with a comparison of Quebec and Catalonia in a book which only deals with CanLit in English, we find that the parallelism is apt because of the minority language and distinct nation status of these two constituencies, and because Quebec and English Canada are coexistent national entities, just like Catalonia and Spain. The parallelism between Catalonia and Quebec has recently been strengthened with the recent upsurge of nationalism and the demand for a referendum to decide whether to become separate from the Spanish state. The story is not new, since as a "historical" autonomous community with a language of its own, Catalan, and a distinct history ${ }^{88}$ and cultural tradition, often at odds with the Spanish ones, Catalonia presents some interesting parallelisms with Quebec, a province with its own language and cultural singularity, which sometimes are also in conflict with those of English Canada.

Over the centuries, Catalan has acquired a strongly political added value, so much so that Catalan identity cannot be understood in isolation from commitment to the language. In fact, as regards language, parallelisms in the linguistic situations of Catalonia and Quebec cannot be overestimated. In Quebec, French has been the only official language since 1977. In spite of this, federal government interventions take place attending to the official status of both French and English in the Federation (Létourneau, 2002) Similarly, in Catalonia both Catalan and Spanish are official, even if only the first is

$\mathbf{8 7}$ We wish to thank August Bové and Jacqueline Hurtley, Professors of Catalan Literature and English literature at the Universitat de Barcelona, for kindly revising this piece.

88 In spite of the union of the Crowns of Aragon and Castille through the marriage of Ferdinand of Aragon and Isabella of Castille in the 15th century, Catalonia remained a different political entity with its own institutions after 1714 (besides its own language) until the 18th century, when it was incorporated into the kingdom of Spain. 
the "llengua pròpia de Catalonia" (Catalonia's own language) according to the Catalan "Estatut" or Statue of Home Rule. Thus, Gade remarks that since the late 1970s Catalonia and Québec "have enjoyed substantial autonomy to chart their own cultural courses" (Gade, 2003) and also that "everywhere in these two polities, language use and policy define issues that remind inhabitants of the need for vigilance in protecting and expanding their minority rights" (Gade, 2003). Indeed both Catalan and Quebecois are islands of linguistic minorities in a sea of speakers of two overwhelmingly powerful languages - Spanish and English. These two hegemonic languages turn out to be menacing for these linguistic communities for different reasons, among which the enormous output of global cultural production in them is one of the most important. ${ }^{89}$

According to Gade (2003), "in Québec, the mother tongue of 81 percent of its 7.4 million people is French. Close to 10 percent of the population speak English as their maternal language and ... [a]nother 10 percent of Québec's population comprise a more fluid multilingual category of immigrants or children of immigrants whose first language is neither French nor English but who use both" (Gade, 2003). In the case of Catalan, it is not spoken in Catalonia only, but also in other autonomous communities, like Valencia and the Balearic Islands, some areas in Aragon (the Franja de Ponent or "Western Fringe"), and Murcia (the area of El Carxe), the independent state of Andorra in the Pyrenees, the Northern Catalonia areas in France (incorporated by this state in the 17th century) and the city of l'Alguer on the Italian island of Sardinia. The legal status of Catalan varies in these territories, being the official language in Andorra and co-official in Catalonia, Valencia and the Balearic Islands. Together with the differences in the legal status, there are also regional variations in the use of Catalan in these areas. ${ }^{90}$ In all, and broadly speaking, some 10 million people can be said to be fluent in Catalan. ${ }^{91}$

89 Other reasons would be, in the case of Quebec, the proximity of a cultural and linguistic giant like the USA (besides the overwhelming presence and use of English in the rest of Canada) and, in Catalonia, the massive arrival of Latin American immigrants who speak only Spanish and are not especially interested in or need to learn Catalan.

90 See the web of the Foundation for Endangered Languages. It should be cautioned here that if considered according to linguistic criteria, Valencian is not perceived as a language different from Catalan (as it is presented, for instance, in the document Selling Canadian Books in Spain). Rather, it is commonly acknowledged, also in most Valencian cultural and political spheres, that Valencian is a variant of Catalan. One of the main Valencian editing houses in Catalan, Bromera, has translated many of Eric Wilson's teenage mystery novels.

91 The overall estimated population who understand Catalan (although they do not necessarily speak it on a daily basis) amounts to 13.529.127 (Generalitat de Catalunya, 2012). 
In spite of the many similarities, there are also differences. For one, the variant of French spoken in Quebec has had to fight off the stigma of being a local and inferior version of European French, which remained the standard for what was not only correct but also chic. Catalan has not had this problem as it has been in charge of setting the norm for itself. There are further differences, some of which are signalled by Daniel W. Gade as follows (we quote the passage at length because it is illustrative of the difficult course of the Catalan language through history, a course which can be matched to Catalonia's own difficult history):

In Catalonia, the Catalan language has a written history that predates by at least 500 years the appearance of French in Québec. Unlike Québec, however, where the British conquest never led to suppression of the language, in Catalonia periods of tolerance for Catalan have alternated with harassment and proscription. [...] A 1716 Bourbon decree imposed Castilian on Catalonia, but not until 1857, when a national network of public schools was established, did the central government in Madrid mandate teaching in Castilian. A diglossia emerged in Catalonia, in which Castilian became the public language and Catalan was left as the home vernacular. Later in the nineteenth century, Catalan re-emerged as part of a larger movement (La Renaixença) toward self-government, education, literary achievement, and economic advancement. The Second Republic (19311939) in Spain built on these developments and gave legal protection to Catalan. [...] The Spanish Civil War (1936-1939) aroused complex allegiances in Catalonia, and language was only part of that equation. After 1970, resistance grew and Madrid loosened its control over these matters somewhat. Franco's demise in 1975 presaged a new vision of a democratic and diverse Spain (Gade, 2003).

Although all the areas where Catalan is spoken make up the so-called "Països Catalans," or "Catalan Countries," a historical and ideological entity that holds strong for most Catalans, Catalan remains an endangered minority language. An expert in endangered languages, ${ }^{92}$ researcher Carme Junyent of the Universitat de Barcelona, places Catalan within the $40 \%$ of languages of the world which show symptoms of replacement. Junyent attributes the detriment of Catalan, which could lead to its extinction, to the use of Spanish among immigrants and to the lack of institutional support (Vernet and Llobet, 2004). Gade (2003) follows this train of thought and indicates the bullying that the Catalan language

92 Carme Junyent participated in the foundation of GELA (The Study Group pro Endangered Languages) - an international association of worldwide linguists - in 1992. 
undergoes not only in the rest of the Spanish peninsula but also within the above mentioned "Catalan Countries":

Since 1975, knowledge and use of Catalan has increased rapidly in Catalonia. Yet it remains an in-group phenomenon, for non-Catalans are rarely expected to speak Catalan even when they understand it. Catalans see their language as a marker of their own shared identity to be used among themselves and, at the same time, manifest the ability to incorporate Castilian seamlessly as an alternative mode of expression. Parallels in grammatical structure and lexical similarities have predisposed most Catalans to become fluent in Castilian, perhaps as much through cultural osmosis as formal study. The rest of Spain makes no such accommodation; indeed, Catalanoparlants [Catalan speakers] have occasionally met with hostility outside their home regions as living representatives of the subversion of Spanish unity (Gade, 2003).

Notwithstanding differences between Quebec and Catalonia, there exist a number of cultural ties. Proof of this proximity is the existence of the Bureau de Québec à Barcelone - the only one in Spain. As María Jesús Bronchal, its Attachée aux Affaires Institutionelles, Publiques et Culturelles, affirmed in an unpublished interview, the institution is very active in the promotion of cultural manifestations of Québec throughout Spain. ${ }^{93}$ Such is the case of outstanding Québecois companies like Cirque du Soleil, Les Sept Doigts de la Main, Cirque Éloize; and relevant personalities of the artistic world: Denys Arcand and Robert Lepage, among others. Bronchal's perception is that in Spain, and more specifically in Catalonia, people are increasingly becoming more aware of the existence of a specifically Québecois culture, distinct from the Anglo-Canadian and the French ones. The exhaustive work carried out by this institution has resulted in a greater familiarity on the part of the Spanish cultural consumers with Canadian culture at large. One of the areas in which the Bureau de Québec has been particularly active is the publishing sector. In 2008 Québec was the Guest of Honour at the 26th International Book Fair in Barcelona, through the invitation of the Federation of Spanish Publishers (Federación del Gremio de Editores Españoles). This event went together with an agreement between Québecois and Catalan cultural institutions to favour the exchange of autochthonous literature through translations. Unfortunately, this agreement has not been as productive as initially expected. Nevertheless, it testifies to the sense of proximity and actual collaboration between the two territories involved. Furthermore, some Catalan institutions which work in

93 The interview with María Jesús Bronchal was held on 15 December 2009. We wish to thank Mrs. Bronchal for her willingness to cooperate, her great kindness and the useful data she provided. 
the publishing and cultural industries have been designed on the Québecois model, as Bronchal pointed out in the same interview.

\section{The Publishing Industry in Catalonia}

Barcelona is a vibrant centre of the Spanish-language publishing industry in Spain and Latin America. The city has long been recognized as an outstanding, first-rank cosmopolitan centre by publishing and cultural standards, not least because in the 1960 s it pioneered the publication of authors like Gabriel García Márquez and Julio Cortázar and was arguably the birthplace, in publishing terms, of the so-called "Boom" of the Latin American novel. The Catalan Institute of Cultural Industries reports that $44.9 \%$ of the overall book production in Spain was generated in Catalonia in 2008. ${ }^{94}$ Ernest Folch (2006), editorial manager of Edicions 62, one of the biggest Catalan publishing houses, recalls that Catalonia is "the world area where more books in Spanish are sold per capita."

But Barcelona is also the capital and cultural centre of Catalonia, the most culturally and economically independent of the Spanish autonomous communities, and as such it owns a full and complex industry devoted to publishing in the Catalan language, itself a language as old as Spanish. Although Ernest Folch (2006) contends that sharing territory with the most important publishing houses in Catalonia makes Spanish-language publishing houses all the more aggressive and undermining for Catalan, at the moment the book industry in Catalan appears to be in very good shape, at least in comparative terms. In fact, no other language without a state supporting it is experiencing an upsurge comparable to that of Catalan, and the main reason for this is the firm investment in continuity and the normalization of the Catalan language. Thus, while it cannot be doubted that in many senses Catalan has suffered the consequences of coexistence with Spanish - also in the area of publishing - with Catalan publishing firms having been absorbed by Spanish ones (Capilla, 2006), some voices suggest that the Catalan publishing industry has benefited from the close contact with the Spanish one: "Without the profit and infrastructures generated by the industry of books in Spanish, it would have been impossible to start and sustain the industry of Catalan books" (Olmos, 2006).

94 See Generalitat de Catalunya (2009), "Dades bàsiques sobre el sector editorial a Catalunya." We wish to thank Iolanda Pelegrí, from the "Institució de les Lletres catalanes," forkindly answering several questions and addressingus to useful sources of information. 
We have seen that the area of reception of works published in Catalan spans an ample territory. However, readership in those areas remains overwhelmingly Spanish. This may be due to several factors, such as the minor visibility in bookstores and libraries of books in Catalan together with their higher price: the fewer copies produced, the higher their cost and therefore their final price, and editions in Catalan are necessarily smaller than their Spanish counterparts (Folch, 2006). Capilla (2006) also suggests that the educational system and cultural institutions in Valencia do not support the Catalan language sufficiently and the argument can be extended to the Balearic Islands.

Usually, a single work is published simultaneously in Spanish and Catalan, in the hope, according to translator and writer Bernat Puigtobella (2008), that "the success of the Spanish edition will help to push the Catalan one up into the best-seller lists." In this context, everything which is translated into Catalan has also been translated into Spanish, but not the other way round. As a result, the reader will seldom take the trouble to investigate whether there is a Catalan version to the more visible (and again, often cheaper) Spanish version of a translated novel. Thus, Catalan is always at risk of seeing itself reduced to being the language of expression of local writers, of either fiction or non-fiction (Puigtobella, 2008). In order to counter this jeopardy, sponsoring policies have been needed and have been systematically put into practice by the Catalan authorities to boost translations from world literature into Catalan. ${ }^{95}$

Neither of the other two minority peninsular languages -Basque and Galiciancompare in size and readership to the publishing industries in Catalan (Capilla, 2006). In this context, it may sound contradictory that an article published recently in the Catalan press should state that "only $32.16 \%$ of the books published in Catalonia, Valencia and the Balearic Islands last year were in Catalan" ("Només el 32,16\%," 2010). This figure is compared to the $57.32 \%$ of books published in Galician and the $45.7 \%$ of books in Basque. Nevertheless, one should not forget that these figures need to be contextualized, bearing in mind the pivotal position of Catalonia in the Spanish book industry. Taking all these aspects into account, the above-mentioned article provides the overall percentages of books in the co-official languages of Spain in 2009, showing that Catalan exceeds the numbers of Basque and Galician (11.2\% in Catalan, $2.5 \%$ in Galician and $1.4 \%$ in Basque).

95 For further information on sponsorship, see the webpage of the Catalan Department of Culture and Communication. Of particular interest are the sections on Cultural Industries and Books and Literature. 


\section{Anglo-Canadian Literature in Catalan: Facts and Figures}

Consultation of two fundamental databases, the ISBN ${ }^{96}$ and the Index Translationum, 97 from 1988 (the year of the foundation of the Spanish Association for Canadian Studies) up until the present, provides information regarding the number of Anglo-Canadian authors whose works have been translated into Catalan in the period in question. The research we carried out shows that a total of thirty-two Anglo-Canadian writers have been translated into Catalan, which amounts to seventy-six publications (including different editions and reprints), among which there are fifty different titles. As regards the publishing houses, and in purely quantitative terms, the most active are Edicions 62; Columna Edicions, Llibres i Comunicació, S.A.; Bromera; Edicions Proa, S.A; Ediciones B, S.A.; and Editorial Cruïlla, S.A. The numbers of translations into Catalan are reflected in Figure 4.1:

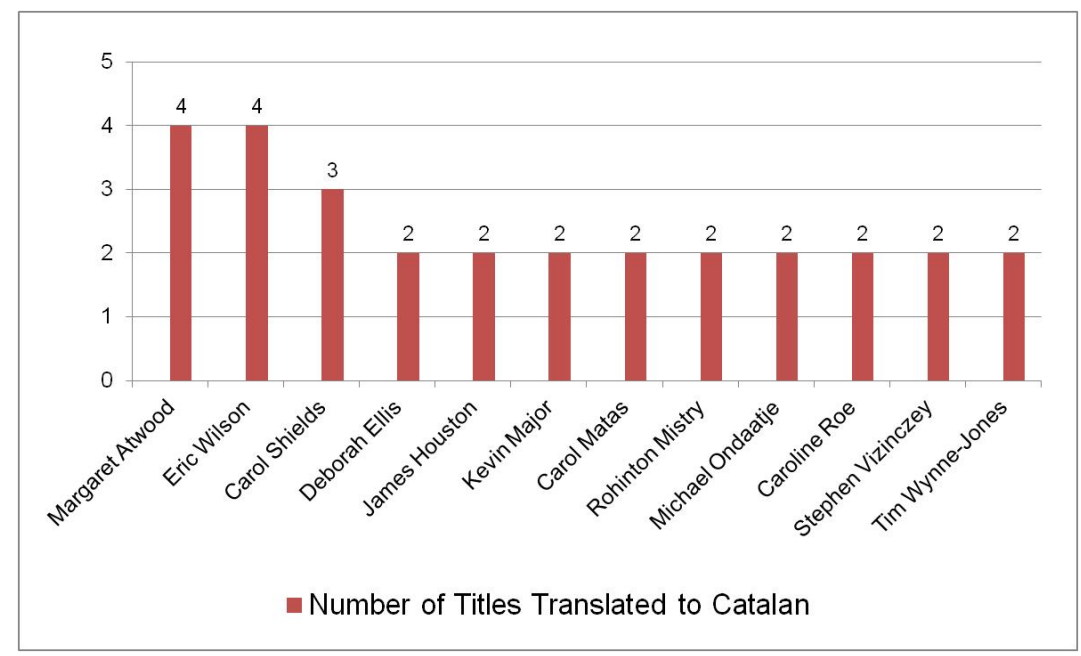

Fig. 4.1 Number of Anglo-Canadian books translated into Catalan.

96 The Spanish International Standard Book Number.

97 The Index Translationum is an international bibliography of translations created in 1932 by the UNESCO. 
Three of them - Edicions 62, Columna, and Proa - currently belong to the publishing group Grup 62. This group, which emerged as an expansion of Edicions 62 (originally founded in 1962), is a major point of reference in the Catalan publishing world and it comprises eighteen publishing houses in Catalan and - interestingly - five publishing houses in Spanish. As regards our object of study, almost $43 \%$ of the translations into Catalan from Anglo-Canadian texts have been published by firms that belong to this group.

Edicions 62, which heads the list, has published the translations of a considerable number of works by authors such as Stephen Vizinczey, Carol Shields, Pauline Gedge, Rohinton Mistry and Caroline Roe, among others. Secondly, Columna Edicions has published the translations into Catalan of Anita Rau Badami, Alan Bradley, Andrew Davidson, Will Ferguson, Barbara Gowdy, James Houston and Yann Martel. In third place is Bromera, a publishing house in Alzira (Valencia) which has published two printings of all the translations into Catalan of children's literature author Eric Wilson. Finally, Proa and Cruïlla have both published translations of Margaret Atwood's texts. Proa, absorbed by Edicions 62 in 2007, has also published translations of Shauna Singh Baldwin and Francis Itani; whereas Cruïlla, only publishes Children's and Youth Literature, like the novels by Tim Wynne-Jones. Ediciones B has been in charge of publishing some of Carol Matas's and Kevin Major's works, who are also included in the category of juvenile literature.

When examining the number of works by Anglo-Canadian authors in translation (see Figure 4.1), it comes as no surprise that Margaret Atwood should head the list, together with Eric Wilson, each with four translated titles. Margaret Atwood's considerable popularity in Spain at the present time responds in part to her having been the recipient of the Prince of Asturias Award in 2008. ${ }^{98}$ Only two of her children's literature books, which had probably been commissioned before news about the prize came out, were published in Catalan that year: D'alt de l'arbre (Up in the Tree) and L'Anna vol tenir un animalet (Anna's Pet, written in collaboration with Joyce C. Barkhouse), and none afterwards. Her latest attempts in the field of speculative fiction, Oryx and Crake (2003) and The Year of the Flood (2009) have still not appeared in a Catalan version.

Before being awarded the Prince of Asturias Award, Ull de gat (Cat's Eye) had been translated in 1990, only two years after its launch and nomination for the 1988 Governor General's Award in Canada and one year after being short listed for the British Booker Prize. ${ }^{99}$ It was published by Edicions de l'Eixample, a relatively

98 See Chapter 2 in this book.

99 Barcelona was the first place that Atwood visited in Spain when she came for a book tour of Cat's Eye in 1990. She returned in 1992 for Pen International Conference and, again, in 1996. This information was provided by Pilar Somacarrera. 


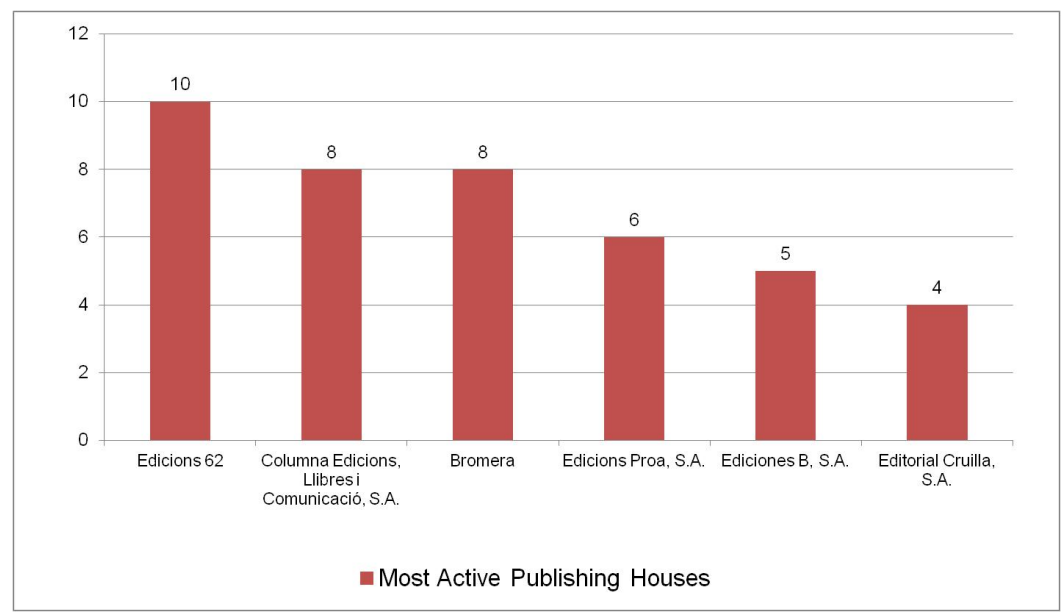

Fig. 4.2 Catalan publishing houses who have published English-Canadian authors

new publishing house (founded in 1984) which included Atwood's novel in its collection "Women's Space." Only when Atwood won the Booker Prize in 2000 for The Blind Assassin was she translated into Catalan again. Its Catalan translation, L'assassí cec, was reissued four times after the first publication in 2001, something unique in the restricted area of Catalan translations of Canadian authors (other comparatively best-selling authors like Kevin Major and Carol Matas have so far only reached three editions each). Among these best-selling authors, the case of Pauline Gedge is worth mentioning. La dama del Nil (Child of the Morning), which combines historical exactitude with romance and was widely distributed in Spanish in collectibles, was published in 1992 and successively reissued in 1996 and 2001. These three editions show Gedge (who was born in New Zealand) as an author as popular as Margaret Atwood in Catalonia because only herself, Atwood and Stephen Vizinczey, together with children's literature best-sellers Kevin Major and Carol Matas have ever reached three editions in Catalan.

\section{Translations of Children's Literature}

Interestingly, the two books by Atwood published in 2008 belong to the category of children's and youth literature, precisely the genre practised by Eric Wilson, a former teacher from British Columbia who now writes children's mystery novels with Canadian settings. The four titles by Wilson published in Catalan are: Assassinat en el Canadian Express (Murder on The Canadian Express, available in Spanish as early as 1982, and with Catalan editions in 1997 and 2009), Pànic 
a Vancouver (Vancouver Nightmare, 1997 and 2008), Terror a Winnipeg (Terror in Winnipeg, 1998 and 2005) and Els vampirs d'Ottawa (Vampires of Ottawa, 1998 and 2006).

This considerable number of translations is not casual: seven out of the twelve Anglo-Canadian authors who have seen two or more of their works translated into Catalan belong to the genre of children's and youth literature: Margaret Atwood and Eric Wilson, but also the following less-known writers: Deborah Ellis, with the works El pa de la Guerra (The Breadwinner, 2004 and 2009 in the Catalan editions) and El viatge de la Parvana (Parvana's Journey, 2004); James Houston, with Diamants negres: a la recerca del tresor artic (Black Diamonds: A Search for Arctic Treasure, 1988) and Foc glaçat: una història de coratge (Frozen Fire: A Tale of Courage, 1994 and 1996); Kevin Major, with Estimat Bruce Springsteen (Dear Bruce Springsteen, 1989, 1992 and 1993) and Lluny de la riba (Far from Shore, 1993); Carol Matas, with Lisa (1989, 1993) and Jesper (2001, 2005, 2006); Tim Wynne-Jones, with Una fuga i una mentida (The Maestro, 1999) and Un lladre a la casa de la memòria (A Thief in the House of Memory, 2006).

In all, ten out of the thirty-two Anglo-Canadian authors translated into Catalan can be placed in the category of children's and youth literature. Joyce Barkhouse, Alan Bradley, and Melanie Watt can also be included with one title each: La bruixa de Port Lajoye (The Witch of Port Lajoye, 1987 and 1989 in its Catalan editions), Els estranys talents de la Flàvia (The Sweetness at the Bottom of the Pie, 2009), and L'Agustina es muda al Pol Nord (Augustine is Moving to the North Pole, 2009), respectively.

There are reasons to explain this phenomenon. On the one hand, Canadian children's literature is a particularly strong area of the Canadian literary system. Adrienne Kertzer (2002) mentions the elements of realistic fiction that place the protagonist in conflict with the wilderness, together with fantasy, as two of its main strengths. But there is a further reason. The document Selling Canadian Books in Spain, edited by the Association for the Export of Canadian Books, states that the impact in the Spanish market of the edition of books written in languages other than Spanish is mainly in textbooks. In this context, we should recall that in Catalonia, as the previous data illustrate, the production and circulation of texts for schools is particularly prominent. By the expression "texts for schools," we refer not only to textbooks, but also to fiction in the Catalan language, including translations, incorporated in primary and secondary education curricula. As stated before, readership in the Catalan countries is overwhelmingly Spanish, but the fact is that primary and secondary education in some of these areas (especially in Catalonia) is conducted fully in Catalan, so much so that Catalan students devote fewer hours per week to the study of Spanish than to the study of English. This means that in the Catalan autonomous community children and teenagers are encouraged to read virtually always in Catalan and only exceptionally in Spanish. As a result, the Catalan market in the 
area of textbooks and fiction is comparatively stronger than that of adult books in Catalan, and also more important than that of children's and youth literature in Spanish published in Catalonia or elsewhere in Spain. Catalans only start reading mostly in Spanish after leaving high school.

\section{Canadian Women Writers Translated Into Catalan}

Outside the realm of children's and youth literature, other Canadian women authors, besides Margaret Atwood, figure prominently in the list of the most translated writers into Catalan, just as they do in the list of Spanish translations. The third position is occupied by Carol Shields. Three of her novels, which are also available in Spanish, have been rendered into Catalan: La memòria de les pedres (The Stone Diaries, Catalan version issued in 1996), which remained in the best-selling list for books in Catalan for several months, El sopar d'en Larry (Larry's Party, 1999), and Deixar-ho tot (Unless, 2003). Given Shields's success as a writer, the fact that the city of Barcelona appears in El sopar de Larry is probably only incidental - although it has been noted in the Catalan press (Huertas, 2003).

Of the two major Canadian women authors of the short story, Mavis Gallant and Alice Munro, who are regarded, together with Atwood and Shields, as "the leading English-Canadian writers of the latter half of the twentieth century" (Thacker, 2009), only Munro has been translated into Catalan. Her belated transference into the Catalan literary system, with the translation of Too Much Happiness (Massa felicitat, Club Editor 2010) and of Hateship...Marriage (Odi, amistat, festeig, amor, matrimoni, Club Editor 2011) comes only after her acceptance in Spain has been solidly established. Quebec-born editor and publisher Anik Lapointe from the publishing group RBA, which has a series in Catalan known as "La Magrana," contributed considerably to make Munro known to Spanish readers. ${ }^{100}$ In an unpublished interview with Lapointe when Munro was still unpublished in Catalan, she suggested that Munro had not been translated, simply, because of the negligibility of the market for books in Catalan. ${ }^{101}$ This negligibility could be one the reasons for the non-existence of

100 For more details about the translation of Munro's works in Spain, see chapter 6 of this volume.

101 The interview was held on 12 January 2010. We wish to thank Mrs. Lapointe for her kindness in answering our questions and providing very interesting insights into the issues under consideration. 
translations of Mavis Gallant's stories into the language, but it could also be attributed to her lack of popularity in Spain.

Shifting from literary fiction to genre fiction, Caroline Roe (a pseudonym of Medora Sale), features in the list of the most translated, this time with two novels: Remedy for Treason (1998) and Cure for a Charlatan (1999), a combination of mystery and historical fiction which originates in the author's research about medieval times. Roe's two novels were rendered into Catalan as Remeïs $i$ Traicions: Cròniques d'Isaac el Cec (1999) and Remei per a un xarlatà (2000). The interest of these translations for Catalan publishers will be clear if we consider that the novels are the first and second parts of the mystery fiction series called "Chronicles of Isaac of Girona," comprising eight books and which are set in the Catalan city of Girona in the 14 th century. A celebratory presentation of the Spanish and Catalan translations of the first novel took place in Girona, a clear example of how a target culture appropriates a foreign text for its own interests. Even the mayor of Girona was present at the book launch, and he praised it enthusiastically, aware no doubt of the possibilities of promotion for Girona and Catalonia created by such a literary feat (Soler, 1999). Unfortunately, only the two titles from the series mentioned above have so far been translated into Catalan (as well as into Spanish.)

Already in the 21st century, we need to highlight a wealth of female Canadian authors, at least in comparative terms. Gail Anderson-Dargatz's A Recipe for Bees was published in 2000 as El secret de les abelles; Bonnie Burnard's A Good House came out as Una bona casa in 2001; Frances Itani's Deafening became Sordesa in 2004; and in the same year Mary Lawson's Crow Lake became A la vora del llac. All titles were published by Edicions 62, except Itani's which was released by Proa, in the same year that it was released in Spanish by publisher Maeva in Madrid. Other interesting examples of women's fiction published in Catalan by RBA's Catalan collection "La Magrana" and mentioned by Anik Lapointe in the interview, are Stef Penny's best-selling novel - soon to be made into a film - The Tenderness of Wolves (La tendresa dels llops, translated 2009); and Nancy Huston's Lignes de Faille (Línies de falla, translated 2008). These works do not strictly fit our corpus but, nevertheless, speak about the shifting and elusive nature of CanLit, as Stef Penny was born in Scotland, although her novel is set in 19th-century Canada; and Nancy Huston, albeit born in Alberta, now lives in Paris and writes in French.

\section{Multicultural Authors}

Stephen Vizinczey, an author of Hungarian origins who has lived in Canada since the 1950 s has had four Catalan editions of his best-selling novel In Praise of Older Women, first published in 1965 and made into a film featuring actor 
Tom Berenger in 1978. The first translation into Spanish by Círculo de Lectores dates from 1989 and it was subsequently translated into Catalan in 1994. It was probably the success of the Spanish editions due to its erotic content (the blurb on the poster of the film hailed it as "A sexual coming of age classic"), which prompted translation into Catalan. There have been three more editions in Catalan, four in all: another in the same year, one in 2002 and one as recently as 2007. In the last of these, the title in Catalan was changed from En Lloança de les dones madures: memòries eròtiques d'Andras Vajda to the more pointed Elogi de les dones madures. Vicenczey's second translated work, Un millionari innocent (An Innocent Millionaire) also reached two editions, both in 1996.

South Asian Canadian authors have also been imported into the Catalan literary system. Rohinton Mistry's A Fine Balance, originally published in 1995 and translated into Spanish three years later, was not transferred into Catalan until 2002 (Un equilibri perfecte), coinciding with the year of the original publication of Mistry's third novel, Family Matters, published in Catalan as Afers de família in 2003. Another South Asian Canadian author who has had two of his books translated is Michael Ondaatje. El fantasma d'Anil (Anil's Ghost) was issued in 2001 and the more recent Divisadero (2007) has also been brought out in a Catalan version (2008). However, it is surprising that despite the great success of Anthony Minghella's film, premiered in 1996 (four years after the novel's publication and Booker Prize award), The English Patient was never translated into Catalan. In this case the Catalan book industry does not seem to follow the trends of the Spanish one, which has selected all of his novels -and even one of his poetry collections, Handwriting - for translation. Perhaps Catalan publishers were pragmatic in deciding that, when buying The English Patient, "in spite of the book cover changed to jibe with the movie's poster, ... [ readers] may be "disappointed with the novel's complex structure, closer to a jigsaw puzzle than to a conventional love story" (Martínez-Zalce, 2001).

It is our perception that these translations and reprintings of Mistry's and Ondaatje's novels respond to the authors' worldwide success rather than to a genuine interest in Canadian letters, and might be understood within the framework of a wider context of enthusiasm in Spain for authors of Indian or South Asian origin (see chapter 3 in this book), to which the selective market of books in Catalan responded immediately. Therefore, it is no coincidence that three further Canadian authors on our list (each with only one translated work), who were published in the same years as Mistry and Ondaatje, have South Asian origins and have therefore drawn on the boom in Indian literature - a paratextual circumstance which, in our view, is independent of the high literary standards of these works. The authors and works in question are Anita Rau Badami, with El cami de l'heroi (The Hero's Walk, Catalan version in 2001), Shauna Singh Baldwin with El que recorda el cos (What the Body Remembers, 2002), and M. G. Vassanji, with La pàtria aliena de V. Lall (The In-Between World of Vikram Lall, 
2006). Lebanese-born Rawi Hage can be listed after the previous authors so as to complete the group of "multicultural" Anglo-Canadian authors translated into Catalan, as his novel El joc de De Niro (De Niro's Game) was translated in 2009. In 2010 the first novel by a native Canadian author was published in Catalan. Tres dies de camí/Three Day Road by Joseph Boyden is described by its publisher Columna as "a magical story, based on real fact, about an Indian from an American tribe who goes to fight in World War I" (Columna webpage, "Tres dies de camí"). The novel is thus marketed as a war novel rather than as a work by a Native Canadian author.

\section{Mainstream and Emerging Canadian Male Authors}

Unlike what has happened with women writers and South Asian Canadian authors, the Catalan market has not paid excessive attention to male authors. From the major male authors of 20th- century Canadian literature, only Timothy Findley was translated in the same century into Catalan, and only one of his books, the mystery novel El joc de les mentides (The Telling of Lies) was published in 1990 by Pòrtic, before the Spanish edition (Últimas palabras) released by Alianza Editorial in 1992.102

Among the remaining authors who each have only one book translated into Catalan, the figure of Robertson Davies comes to the fore. In 2006 Davies's Fifth Business, translated into Spanish as El quinto en discordia the same year, was awarded the "Premi Llibreter", an annual literary award created in 2000 by the Association of Barcelona and Catalan Booksellers (Gremi de Llibreters de Barcelona i Catalunya). The novel had been translated into Spanish and published by Libros del Asteroide, a small but select publishing house based in Barcelona, founded in 2005. After the award the sales of Davies's novel rose from 2000 to 10000 (Ayén, 2007), so the prize was instrumental in making the Spanish reading public acquainted with this great man of Canadian letters. It was after this success that Libros del Asteroide decided to translate the novel into Catalan, and it came out in 2007 as El cinquè en joc. Robertson Davies' way into the Catalan literary system through El cinquè en joc was paved by an introduction by the Balearic writer Valentí Puig and an accurate translation by Carles Miró Jordana. The Catalan version was widely reviewed and praised

102 With only one title published in Catalan and Spanish, Timothy Findley's works remain one of the most blatant absences both in the Catalan and Spanish literary systems. 
in the Catalan-speaking media. So far, and in spite of the huge success of his novels following the "Premi Llibreter," only this one novel by Davies has been translated into Catalan, contrasting with the nine titles that have been rendered into Spanish. Like Robertson Davies, the three remaining names on the short list of prestigious male authors who have only been published once were also safe investments for different reasons. In order of age, the first is Leonard Cohen, who has just been distinguished with the Prince of Asturias Award for Letters of 2011. Needless to say, his prestige as a musician and composer make him a wellknown figure for Spanish and Catalan audiences. Only his novel Bells perdedors (Beautiful Losers) was published by Angle Editorial in 2002, whereas many of Cohen's books have been rendered into Spanish.

The second name is Douglas Coupland, a younger author whose book All Families Are Psychotic was translated into Catalan only one year after the original release, appearing as Totes les famílies son psicòtiques (2002). As explored elsewhere in this book (see chapter 7), Coupland was a well-known author by then in Spain; the Spanish version of Generation $X$ went through a number of editions and all his other works had been automatically translated into Spanish as they were produced. Again, it is worth noting the contrast between the eighteen editions of the different works of Douglas Coupland in Spanish and only one existing in Catalan. As is the case with Robertson Davies, this huge gap illustrates the limitations of the book market in Catalan.

The third well-known author is Yann Martel, whose birth in Salamanca in 1963 may have made him more popular among some Spanish readers. His Booker Prize-winning novel Life of Pi was published in 2003 as Vida de Pi in both Spanish and Catalan, the similarities between the two languages due to their common origin in vulgar Latin resulting in a identical title for each edition. The book has so far reached six editions in Spanish, and although it sold very well, it has never reached a second edition in Catalan.

In the section of emerging authors we can situate Will Ferguson and Andrew Davidson, whose novels were published in Catalan in the same year of their release in English, possibly preceded by their international commercial success. Ferguson (born in 1964), a prolific critic of Canadian society and culture, is represented by his book Happiness (Felicitat in its Catalan version), a satire on self-help books, published in Catalan and Spanish in 2002. Andrew Davidson, an author of the same generation as Will Ferguson, was transferred into the Catalan literary system through a psychological thriller about love, illness and medieval history. The Gargoyl, whose rights had already been sold to 25 countries when it was published in Spanish by Seix Barral in 2008 (Mendoza, 2008), came out in Catalan as La gàrgola in the same year.

One is tempted to ponder the reasons for this relatively high number of Canadian authors translated into Catalan at the beginning of the 21st century (we should bear in mind that many South Asian Canadian and Canadian authors 
of children's literature were also translated in the same period), and several explanations can be found. First of all, we should consider the high quality and ever-increasing status of Canadian literature in the global literary field. In addition, and on a more material level, this presence can be perceived - if only partially - as a consequence of the above-mentioned institutional initiatives to promote exchanges between authors of Canadian and Catalan origin. Whereas the agreement between the Québecois and Catalan cultural institutions affected mostly French Canadian authors, it can be argued that it encouraged a better knowledge of Canadian literature in general and stimulated a greater interest in it. In addition, the Canadian consulate in Barcelona actively contributes to the export of Canadian books into Catalonia (and Spain) by establishing contacts between Catalan publishers and Canadian publishers and literary agents at international book fairs. ${ }^{103}$ Finally, as Anik Lapointe pointed out, it has been economically advantageous for literary agents to represent - and for publishing houses to buy - the rights of Canadian emerging writers because in general terms they are cheaper than their USA counterparts, whereas their literary quality is by no means inferior.

\section{Conclusions}

As we highlighted at the beginning of this chapter, Catalonia is politically and linguistically singular, and Catalan is not only spoken in Catalonia but, to a greater or lesser degree, in all the area referred to as the Països Catalans. In spite of the differences pointed out in this article (and possibly others), there are many aspects common to both the Catalan and Quebecois political situations and socio-cultural realities, particularly in the area of language. In both territories there is a language which, regardless of its official status, is perceived by the majority as their own, but which has to coexist with another hegemonic language which turns out to be menacing and even undermining.

In Catalonia, as in other areas of the "Catalan Countries," supportive institutional policies have been in place for years. Together with the strong feeling Catalans have for their language and the solid sense of identity which emerges from a history of resilience against all too frequent political odds, these policies have resulted in a solid corpus of literature in the Catalan language, both original and in translations, quantitatively unmatched in any of the other Spanish

103 Information provided by Pilar Somacarrera, obtained in a private conversation with Lesley-Anne Reed, Consul and Trade Commissioner of Canada in Barcelona at the seminar "Barometer of the relations between Spain and Canada," organized by the Chamber of Commerce Canada-Spain on February 21, 2011. 
autonomous communities. Barcelona is one of the main world centres of the book industry in Spanish, and the undeniable focus of production for books in Catalan. The propinquity of these two industries has sometimes been perceived as positive for the one in Catalan, as the major publishing houses in Spanish may have provided a ready industry (infrastructures, printing machinery, etc.) for book production in Catalan. However, it has more generally been perceived as negative, because of the big pressure that coexistence with the huge Spanish market puts on the more limited market in Catalan, which is currently classified as a language at risk.

The corpus of translations into Catalan of works by Anglo-Canadians since 1988 can be broadly categorized in five groups: (1) literature for children and teenagers; (2) consecrated Canadian authors; (3) multicultural authors (especially South Asian Canadians); (4) Canadian best-sellers and (5) emerging Canadian authors. After reviewing the different names, titles and number of editions in each category, we conclude that, given the size and scope of the publication of books in Catalan, Anglo-Canadian works are translated into Catalan only when there is a virtual guarantee of commercial success or because these authors have already achieved sales in the Spanish-language market. Authors included in the first four categories enumerated above seem to respond to this dynamic for one reason or another and sometimes for more than one as would be the case with Margaret Atwood - a consecrated author, highly distinguished in terms of awards, a safe bet in terms of literary quality, and a bestseller in English-speaking countries. ${ }^{104}$ In terms of genre, the Catalan publishing industry has not risked much, either. Only novels, several of which can be included in the category of formula fiction - mysteries or romances with a tinge of historical fiction - or the safe wager of children's literature have been released. Not a single volume of poetry or nonfiction can be traced in our list of English-Canadian volumes translated into Catalan, not even works by Atwood who excels at both such genres.

However, in the restricted landscape of translations into Catalan, Atwood emerges once again as the queen of Canadian letters in English. She is arguably the most translated and the best-known Canadian writer in the Catalan Countries. Yet, as such, the relatively small number of works by this prolific author which have so far been rendered into Catalan can be read as symptomatic of the overall health of the industry of (translated) books in Catalan. It is remarkable, however, that none of her novels for adults has been published in Catalan after L'assessi cec (The Blind Assassin) in 2001, which might be explained by the lower sales her books in Spanish have at the moment.

$\mathbf{1 0 4}$ Her condition as a best-selling author in Spanish will be addressed in chapter 5 of this volume. 
As we were concluding this chapter, the cultural supplement of El Mundo, a right-leaning Spanish journal issued in Madrid, published an article titled "Late News on the Edition in Catalan" (Azancot, 2010). The article provides a summary of controversial issues with regard to this field, such as the question of institutional support for the book in Catalan. Several authors and professionals hold different views on this question. For some, it has helped develop an indispensable corpus of literary works in Catalan; for others, it has negatively influenced a bilingual society in which Catalan writers who express themselves in Spanish find themselves at a disadvantage; while still others go as far as claiming that systematic funding has curtailed creativity. Against these voices critical of institutional support, Catalan poet Miquel de Palol, regrets that it is insufficient (quoted in Azancot, 2010), while poet Alex Susanna claims the need to enhance the ecolinguistic consciousness in Spain (quoted in Azancot, 2010). Overall, while the sales and number of titles published in Catalan have fallen because of the global economic crisis, the directors of several series in Catalan seem to agree that there is stability and continuity in the market, with a faithful readership in Catalan. It is apparent that both the situation and the interpretation of data are highly politicized, to the extent that many authors and professionals prefer to keep their opinions to themselves.

In conclusion, considering the specificity of the socio-political and linguistic situation in Catalonia, and comparing the number of Anglo-Canadian books published in languages other than Spanish in other historical autonomous communities (the Basque Country and Galicia), we need to acknowledge that the body of works of Anglo-Canadian authors translated so far into Catalan is not negligible, but rather the contrary. We would venture to say that perspectives for the future seem optimistic, in the light of following factors related to both source and target cultures: the rising value of CanLit in Catalonia and Spain, the direct and indirect effects of the institutional support from the Canadian government and the Quebec Mission, the strength of the book industry in Barcelona and, finally, the cosmopolitan and highly literate nature of Catalan society. 